\title{
Efektivitas Kernel Kelor dan Ampas Kernel Kelor (Moringa oleifera L.) sebagai Biokoagulan dan Desinfektan Alami pada Pengolahan Air Sungai
}

\section{Effectiveness seed and seed cake of Moringa Oleifera L. as Biocoagulants and Disinfectants in River Water Treatment}

\author{
Irmayanti $^{1)}$, Chairil Anwar ${ }^{2)}$, Ika Rezvani Aprita ${ }^{2)}$ \\ ${ }^{1}$ Teknik Industri Pertanian, Universitas Serambi Mekkah, \\ Jl. T. Imum Lueng Bata, Banda Aceh, INDONESIA \\ ${ }^{2}$ Teknologi Pengolahan Hasil Ternak, Politeknik Indonesia, \\ Jl. Bandara Sultan Iskandar Muda Km 12 Kabupaten Aceh Besar, INDONESIA \\ *corresponding author, email: irmayanti@serambimekkah.ac.id
}

Manuscript received: 17-04-2019. Accepted: 18-05-2019

\begin{abstract}
ABSTRAK
Penelitian ini secara khusus bertujuan untuk mempelajari keefektifan serbuk kernel kelor dan ampas kernel kelor (Moringa oleifera L.) sebagai biokoagulan dan desinfektan pada pengolahan air sungai. Penelitian ini menggunakan Rancangan Acak Kelompok (RAK) pola faktorial dengan empat kali ulangan. Perlakuan dalam penelitian ini terdiri dari 2 faktor, faktor biokoagulan (v) dan konsentrasi serbuk kernel kelor dan serbuk ampas kernel kelor (k). Faktor biokoagulan alami terdiri dari 2 taraf, yaitu serbuk kernel kelor $\left(\mathrm{v}_{1}\right)$ dan serbuk ampas kernel kelor $\left(\mathrm{v}_{2}\right)$, faktor konsentrasi serbuk kernel kelor dan serbuk ampas kernel kelor terdiri dari 3 taraf, yaitu $0,025 \%\left(\mathrm{k}_{1}\right), 0,05 \%\left(\mathrm{k}_{2}\right)$ dan $0,075 \%\left(\mathrm{k}_{3}\right)$. Analisis yang dilakukan terhadap air sungai, air olahan dan air setelah penyaringan meliputi nilai $\mathrm{pH}$, warna, kekeruhan, kadar mangan (Mn), kadar besi (Fe), dan bakteri koli total. Air olahan kualitas terbaik diperoleh setelah perlakuan serbuk biji kelor $\left(\mathrm{v}_{1}\right)$ dengan konsentrasi $0,05 \%\left(\mathrm{k}_{2}\right)$ dengan karakteristik sebagai berikut : pH 7,21, warna 11,25 TCU (True Colour Units), kekeruhan 2,38 NTU (Nephelometric Turbidity Units), kadar mangan (Mn) 0,022 mg. $\mathrm{L}^{-1}$, kadar besi 0,036 mg...-1, dan bakteri koli total $0,08 \times 10^{2} / 100 \mathrm{ml}$ sampel.
\end{abstract}

Kata kunci: air bersih; kekeruhan; mangan; besi

ABSTRACT
This study specifically aims to study the effectiveness of Moringa oleifera L. Moringa oleifera seed
powder as a biocoagulant and disinfectant for river water treatment. This study use a factorial
randomized block design (RBD) with four replications. The treatment in this study consisted of 2
factors, the variation factor of biocoagulants (v) and the biooagulants concentration (k). Moringa seed
variation factor consists of 2 levels, namely Moringa seed powder (v1) and Moringa seed pulp (v2)
powder, the factor of Moringa seed powder concentration and Moringa seed pulp powder consists of 3


levels, namely $0.025 \%(\mathrm{k} 1), 0.05 \%(\mathrm{k} 2)$ and $0.075 \%(\mathrm{k} 3)$. Analysis carried out on river water, treated water and water after screening included $\mathrm{pH}$, color, turbidity, manganese $(\mathrm{Mn})$, iron $(\mathrm{Fe})$ and total coli bacteria. The best quality processed water is treated with Moringa (v1) seed powder with a concentration of $0.05 \%(\mathrm{k} 2)$ with the following characteristics: $\mathrm{pH} 7.21$, color $11.25 \mathrm{TCU}$ (True Color Units), turbidity $2.38 \mathrm{NTU}$ (Nephelometric Turbidity Units), manganese (Mn) levels $0.022 \mathrm{mg.L} \mathrm{L}^{-1}$, iron content $0.036 \mathrm{mg} . \mathrm{L}^{-1}$, and coli bacteria total $0.08 \times 102 / 100 \mathrm{ml}$ samples.

Keyword: clean water; tubidity; manganese; iron.

\section{PENDAHULUAN}

Air merupakan sumber daya alam yang diperlukan untuk semua makluk hidup. Oleh karena itu sumber daya air tersebut harus dilindungi agar dapat dimanfaatkan dengan baik oleh manusia dan makhluk hidup lainnya (Nugroho, 2008). Salah satu sumber air yang banyak dimanfaatkan untuk memenuhi kebutuhan hidup manusia dan makhluk hidup lainnya yaitu sungai. Sungai merupakan ekosistem yang sangat penting bagi manusia. Sungai juga menyediakan air bagi manusia untuk berbagai kegiatan seperti pertanian, industri maupun domestik (Siahaan et al., 2011). Air yang berwarna bahkan berbau kemungkinan telah tercemar atau terkontaminasi dengan bakteri-bakteri yang dapat membahayakan jiwa manusia dengan menimbulkan berbagai penyakit. Karena alasan tersebut, sebelum air sungai dapat digunakan untuk memenuhi kebutuhan keluarga, sangat diperlukan tindakan untuk membersihkan bahanbahan pencemar yang terbawa.

Salah satu alternatif yang tersedia secara lokal adalah penggunaan koagulan alami dari tanaman yang dapat diperoleh di sekitar kita yakni tanaman kelor (Moringa oleifera L.) atau lebih dikenal sebagai bak murong dalam bahasa Aceh. Kelor adalah sejenis tumbuhan yang mampu tumbuh subur mulai dataran rendah sampai ketinggian 700 meter diatas permukaan laut. Biji dari tumbuhan ini mengandung zat aktif (4-Alfa-4- Ramnosiloksi-BenzilIsotiosianat) yang dapat digunakan sebagai koagulan alami pada proses penjernihan air (Haslinah, 2016).

Penggunaan koagulan alami dilakukan sedapat mungkin digunakan guna mengurangi penggunaan bahan sintesis dengan tujuan back to natural. Koagulan biji kelor (Moringa oleifera) telah memberikan keuntungan dibandingkan dengan bahan sintesis lainnya karena bersifat alami dan dilaporkan dapat dikonsumsi. Biaya penggunaan koagulan alami ini akan lebih murah dibandingkan penggunaan koagulan yang biasa digunakan (alum) untuk pemurnian air (Yuliastri, 2010).

Secara umum penelitian ini bertujuan untuk mencari bahan alternatif pengganti tawas $\left(\mathrm{Al}_{2}\left(\mathrm{SO}_{4}\right)_{3}\right)$ dan bahan desinfektan (kaporit dan klorin) dalam rangka meningkatkan kualitas air bersih di Provinsi NAD. Secara khusus penelitian ini bertujuan untuk mempelajari keefektifan serbuk biji kelor dan ampas biji kelor (Moringa oleifera L.) sebagai bahan koagulan dan desinfektan alami pada pengolahan air sungai.

\section{Bahan dan Alat}

\section{BAHAN DAN METODE}

Bahan-bahan yang digunakan pada penelitian ini adalah kernel kelor kering (Moringa oleifera L.) dengan kadar air (23.6\%) yang diperoleh dari kawasan Darussalam dan air sungai diperoleh dari PDAM yang berasal dari Krueng Aceh, Kabupaten Aceh Besar, Provinsi Aceh. Bahan-bahan kimia yang digunakan untuk analisis adalah dietil eter, aquades, sodium permangat, reagent mangan, reagent fero, medium MF ebd, EDTA 15\%, alkohol 95\%, $\mathrm{NaOH}$ $1 \mathrm{~N}$, alkohol 70\%, $\mathrm{KH}_{2} \mathrm{PO}_{4}, \mathrm{MgSO}_{4} .7 \mathrm{H}_{2} \mathrm{O}$, dan $\mathrm{Na}_{2} \mathrm{~S}_{2} \mathrm{O}_{3} 10 \%$. 
Alat-alat yang digunakan untuk pengolahan air adalah blender kering, gelas kimia, timbangan analitik Tanika, ayakan Tyler 60 mesh, seperangkat alat soxhlet, dan tes jar. Alatalat yang digunakan untuk analisis adalah $\mathrm{pH}$ meter (TOA V EMI), turbidimetri AS $2100 \mathrm{P}$, spektrofotometer YR/2000 AS, botol sampel steril, labu erlenmeyer $250 \mathrm{ml}$ dan $500 \mathrm{ml}$, cawan petri steril, autoklaf, alat filtrasi diameter $47 \mathrm{~mm}$ kapasitas $100 \mathrm{ml}$ dilengkapi pompa vakum untuk penyaringan sampel pada uji bakteri koli total, inkubator, kertas penyerap, water bath, gelas kimia, gelas ukur, serbet dan pipet tetes.

\section{Rancangan Percobaan}

Penelitian ini menggunakan Rancangan Acak Kelompok (RAK) pola faktorial dengan 4 kali ulangan. Perlakuannya terdiri dari 2 faktor, faktor biokoagulan (v) dan konsentrasi serbuk kernel kelor dan serbuk ampas kernel kelor (k). Faktor biokoagulan terdiri dari 2 taraf, yaitu serbuk kernel kelor $\left(\mathrm{v}_{1}\right)$ dan serbuk ampas kernel kelor $\left(\mathrm{v}_{2}\right)$, faktor konsentrasi biokoagulan terdiri dari 3 taraf, yaitu $0.025 \%\left(\mathrm{k}_{1}\right), 0.05 \%\left(\mathrm{k}_{2}\right)$ dan $0.075 \%\left(\mathrm{k}_{3}\right)$, sehingga kombinasi perlakuan yang diperoleh 24 satuan percobaan.

\section{Pelaksanaan Penelitian}

Penyiapan kernel kelor. Buah kelor (Moringa oleifera L.) yang sudah kering dikupas kulitnya dan dibersihkan, sehingga menghasilkan isi kernel yang putih. Kemudian kernel dikeringkan di bawah sinar matahari selama \pm 2 hari (kadar air 23.6\%). Kernel yang sudah kering (kadar air $23.6 \%$ ) dihaluskan dengan blender kering. Kernel yang sudah halus diayak dengan menggunakan ayakan Tyler 60 mesh sehingga menghasilkan serbuk kernel kelor.

Penyiapan ampas kernel kelor. Serbuk kernel kelor yang dihasilkan diekstrak dengan soxhlet memakai pelarut dietil eter untuk mengekstrak minyak yang terkandung di dalam biji kelor, kemudian serbuk ampas yang dihasilkan diuapkan di dalam oven selama 3 jam, sehingga menghasilkan serbuk ampas kernel kelor dengan kadar air 5.6\%.

Pengolahan air bersih dengan menggunakan serbuk dan ampas kernel kelor. Serbuk kernel atau serbuk ampas kernel kelor ditimbang berdasarkan perlakuan $0.025 \%\left(\mathrm{k}_{1}\right), 0.05 \%$ $\left(\mathrm{k}_{2}\right)$ dan $0.075 \%\left(\mathrm{k}_{3}\right)$. Serbuk dan ampas kernel kelor dimasukkan ke dalam sendok dan diberi air secukupnya hingga membentuk pasta. Pasta serbuk kernel kelor dan ampas kernel kelor dicampurkan dengan air yang akan dijernihkan. Air yang dijernihkan diaduk dengan kecepatan $140 \mathrm{rpm}$ selama 17 menit dengan menggunakan agitator, kemudian diaduk secara berlahan dengan kecepatan 35 rpm selama 5 menit. Air didiamkan selama 1 jam. Air hasil olahan dipisahkan dari endapan secara perlahan dengan menggunakan selang. Perlahan-lahan dilakukan agar endapan tidak naik ke permukaan. Seluruh sampel air hasil olahan dianalisis untuk mendapatkan data penelitian.

\section{Analisis Data}

Analisis yang dilakukan pada penelitian ini yaitu nilai $\mathrm{pH}$, warna, kekeruhan, kadar mangan, kadar besi, dan bakteri koli total dengan 4 kali ulangan. Data yang diperoleh selanjutnya dianalisis statistik dengan menggunakan tabel ANOVA. Apabila perlakuan terdapat pengaruh nyata maka dilakukan uji lanjut Beda Nyata Terkecil (BNT).

\section{Nilai $\mathrm{pH}$}

\section{HASIL DAN PEMBAHASAN}

Berdasarkan hasil analisis, nilai $\mathrm{pH}$ air olahan yang dihasilkan dengan menggunakan serbuk kernel kelor dan serbuk ampas kernel kelor berkisar antara 7,14 - 7,53, dengan rata-rata nilai $\mathrm{pH} 7,32$. Hasil analisis sidik ragam menunjukkan bahwa faktor perlakuan biokoagulan 
dan perlakuan konsentrasi bahan koagulan alami berpengaruh sangat nyata $(\mathrm{P} \leq 0.01)$ terhadap $\mathrm{pH}$ air olahan yang dihasilkan, sedangkan interaksi antar perlakuan berpengaruh tidak nyata $(\mathrm{P}>0.05)$ terhadap $\mathrm{pH}$ air olahan yang dihasilkan.

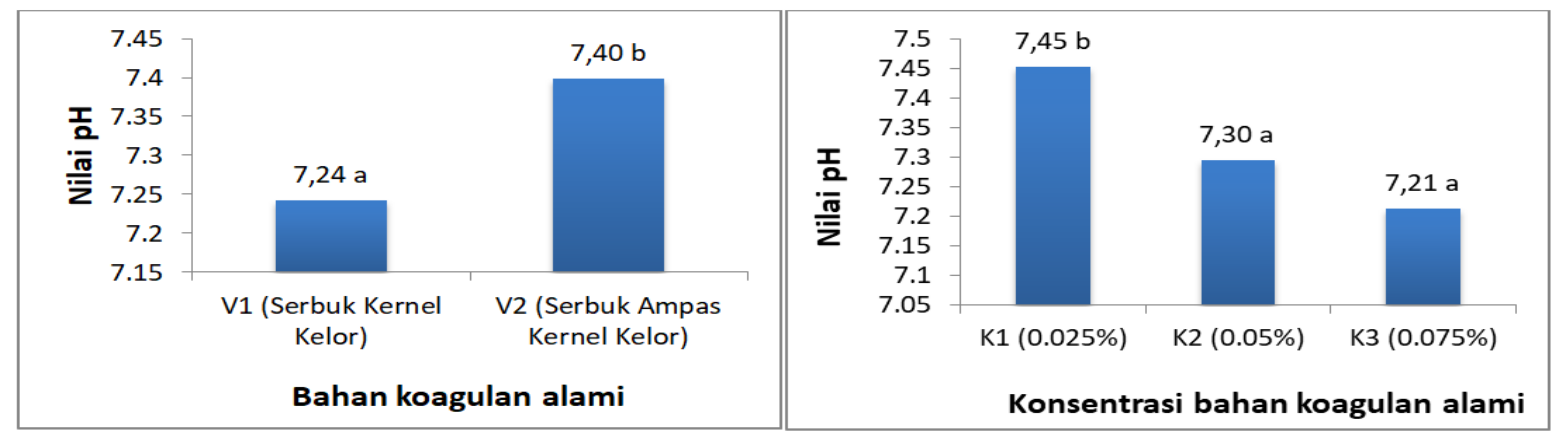

Gambar 1. Pengaruh biokoagulan terhadap $\mathrm{pH}$ air olahan dan konsentrasi biokoagulan terhadap $\mathrm{pH}$ air olahan yang dihasilkan

Gambar 1 menunjukkan bahwa nilai $\mathrm{pH}$ air olahan yang dihasilkan dari serbuk kernel kelor lebih rendah (7.24) dibandingkan dengan serbuk ampas kernel kelor (7.40). Nilai pH air olahan yang dihasilkan dari ketiga konsentrasi serbuk kernel kelor dan serbuk ampas kernel kelor cenderung berubah tetapi masih berada diatas nilai $\mathrm{pH}$ air sungai sebelum diolah. Hal ini mengindikasikan bahwa serbuk kernel kelor dan serbuk ampas kernel kelor mampu mengurangi keasaman air dan tidak menurunkan nilai $\mathrm{pH}$ air pada saat koagulasi berlangsung.

Tingkat kemasaman $(\mathrm{pH})$ dapat mempengaruhi kelarutan dari suatu koagulan. Semakin mudah larut suatu koagulan, maka semakin mudah terbentuknya ion aquometalik yang akhirnya semakin cepatnya partikel koloid ternetralisasi membentuk flok. Semakin besar $\mathrm{pH}$, maka kelarutan dari bahan koagulan semakin kecil, sehingga ion aquametalik semakin sulit terbentuk, yang akhirnya mengurangi jumlah partikel koloid yang dapat ternetralisasi membentuk flok (Karamah dan Septiyanto, 2010).

\section{Warna}

Intensitas warna air olahan dengan menggunakan serbuk kernel kelor dan serbuk ampas kernel kelor berkisar antara 9,25-16,00 TCU. Warna rata-rata yang dihasilkan adalah 12.17 TCU. Hasil analisis sidik ragam menunjukkan bahwa faktor perlakuan biokoagulan berpengaruh nyata $(\mathrm{P} \leq 0.05)$ terhadap warna air olahan yang dihasilkan dan faktor perlakuan konsentrasi biokoagulan berpengaruh sangat nyata $(\mathrm{P} \leq 0.01)$ terhadap warna air olahan yang dihasilkan, sedangkan interaksi antar perlakuan berpengaruh tidak nyata $(\mathrm{P}>0.05)$ terhadap warna air olahan yang dihasilkan.

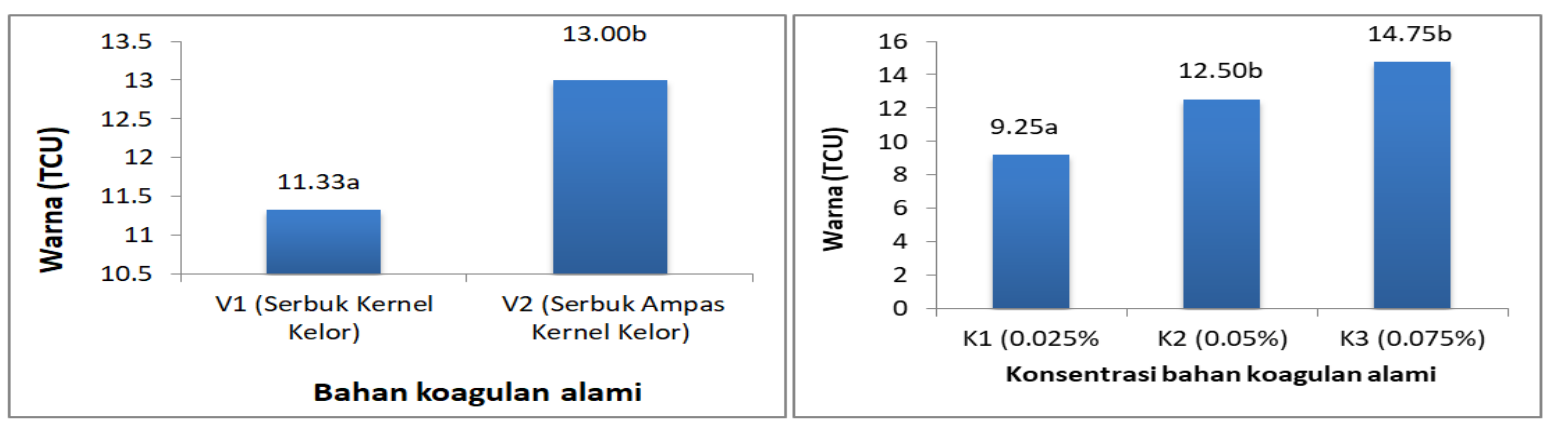

Gambar 2. Pengaruh variasi biokoagulan terhadap warna air olahan dan konsentrasi biokoagulan terhadap warna air olahan yang dihasilkan 
Gambar 2, menunjukkan bahwa warna air olahan yang dihasilkan dari serbuk kernel kelor lebih rendah dibandingkan dengan serbuk ampas kernel kelor. Hal ini diduga serbuk kernel kelor lebih banyak mengandung zat rhamnosyloxy-benzil-isothiocyanate sehingga lebih cepat menetralisir partikel-partikel lumpur dan kotoran lainnya pada saat terjadinya koagulasi. Menurut Amir (2010), penurunan intensitas warna pada air karena adanya muatan positif dari koagulan yang menetralkan muatan negatif partikel koloid sehingga terbentuklah flok. Sedangkan serbuk ampas kernel kelor lebih banyak tersuspensi di dalam air karena zat koagulannya tidak bekerja dengan baik akibat proses ektraksi, sehingga intensitas warna air yang dihasilkan lebih tinggi.

Warna air olahan yang dihasilkan pada konsentrasi biokoagulan $0.025 \%$ lebih rendah dan berbeda sangat nyata dengan konsentrasi $0.05 \%$ dan $0.075 \%$. Konsentrasi biokoagulan yang tinggi menyebabkan terjadinya overdosis, yang akan mengakibatkan kejenuhan dari koagulan. Hal ini diakibatkan dari re-stabilisasi dan destabilisasi partikel. Biji Moringa oleifera adalah suatu polielektrolit kationik, maka dengan semakin meningkatnya konsentrasi akan menyebabkan re-stabilisasi partikel yang telah didestabilisasi. Hal inilah yang akan meningkatkan kekeruhan dan warna terhadap air yang dihasilkan (Muyibi dan Evison, 1995).

\section{Kekeruhan}

Kekeruhan air olahan dengan menggunakan serbuk kernel kelor dan serbuk ampas kernel kelor berkisar antara 2.10-3.99 NTU. Kekeruhan rata-rata yang dihasilkan adalah 3.08 NTU. Hasil analisis sidik ragam menunjukkan bahwa faktor perlakuan bahan koagulan alami berpengaruh sangat nyata $(\mathrm{P} \leq 0.01)$ terhadap kekeruhan air olahan yang dihasilkan, sedangkan perlakuan konsentrasi bahan koagulan alami serta interaksi antar perlakuan berpengaruh tidak nyata $(\mathrm{P}>0.05)$ terhadap kekeruhan air olahan yang dihasilkan.

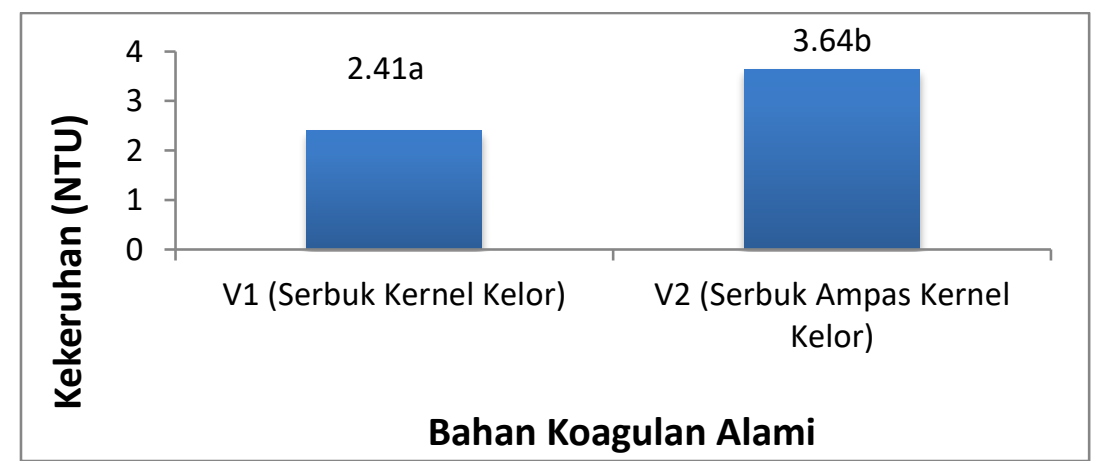

Gambar 3. Pengaruh variasi biokoagulan terhadap kekeruhan air olahan yang dihasilkan

Gambar 3 menunjukkan bahwa kekeruhan air olahan yang dihasilkan dari serbuk kernel kelor lebih rendah dan berbeda sangat nyata dengan serbuk ampas kernel kelor. Biji Moringa oleifera dikenal sebagai suatu polielektrolit kationik. Oleh karena itu jika jumlah optimum dosis dari biji Moringa oleifera sebanding dengan ukuran dari partikel tersuspensi maka partikel berukuran kecil akan selalu menghasilkan massa flok yang lebih besar (Muyibi dan Evison, 1995). Penurunan nilai kekeruhan ini disebabkan makroflok yang terbentuk mengandung material koloid yang sebelumnya terdispersi pada air. Nilai kekeruhan yang bervariasi bisa disebabkan oleh restabilisasi koloid yang terjadi karena muatan yang masih reaktif pada permukaan koloid (Widyaningsih, 2011). 


\section{Kadar Mangan (Mn)}

Kadar mangan air olahan dengan menggunakan serbuk kernel kelor dan serbuk ampas kernel kelor berkisar antara 0,013-0,047 mg/L. Kadar mangan rata-rata yang dihasilkan adalah $0,029 \mathrm{mg} / \mathrm{L}$. Hasil analisis sidik ragam menunjukkan bahwa faktor perlakuan bahan koagulan alami dan perlakuan konsentrasi bahan koagulan alami berpengaruh sangat nyata $(P \leq 0,01)$ terhadap kadar mangan air olahan yang dihasilkan, sedangkan interaksi antar perlakuan berpengaruh tidak nyata $(\mathrm{P}>0,05)$ terhadap kadar mangan air olahan yang dihasilkan.

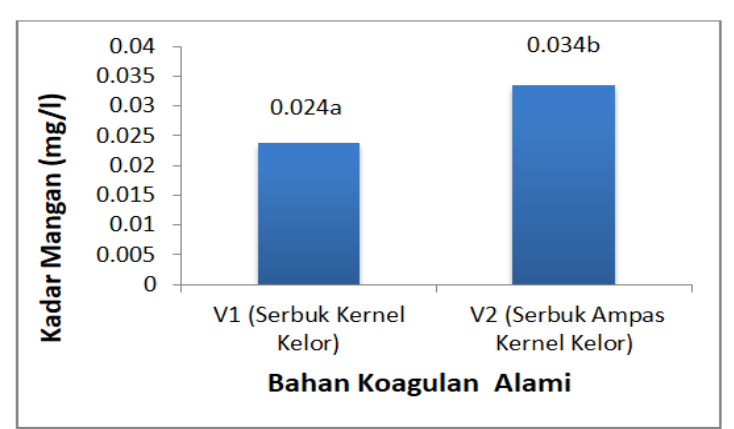

Gambar 4. Pengaruh biokoagulan terhadap

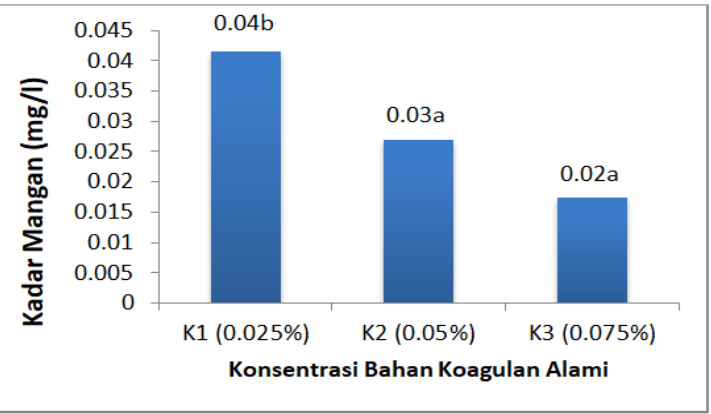
kadar mangan air olahan dan konsentrasi biokoagulan terhadap kadar mangan air olahan yang dihasilkan

Gambar 4 menunjukkan bahwa kadar mangan air olahan yang dihasilkan dari serbuk kernel kelor lebih rendah dan berbeda sangat nyata dengan serbuk ampas kernel kelor. Menurut Sutrisno (1996), penambahan bahan koagulan ke dalam air akan mempercepat proses koagulasi. Selama proses koagulasi berlangsung komponen-komponen kimia yang mencemari air akan ikut membentuk gumpalan, salah satunya adalah kation-kation penyebab kesadahan seperti $\mathrm{Cl}, \mathrm{Mn}, \mathrm{SO}_{4}$ dan Fe. Kadar mangan air olahan yang dihasilkan pada konsentrasi bahan koagulan alami $0.025 \%$ lebih tinggi dan berbeda sangat nyata dengan konsentrasi $0.05 \%$. Hal ini di duga pada konsentrasi $0.05 \%$ dan $0.075 \%$ serbuk kernel kelor dan serbuk ampas biji kernel lebih lebih banyak mengandung zat aktif rhamnosyloxy-benzil-isothiocyanate, sehingga lebih efektif mengurangi kadar mangan yang terkandung di dalam air sungai.

Berdasarkan hasil analisis, dapat diketahui bahwa jenis biokoagulan biji asam jawa tidak memiliki kemampuan untuk mengurangi kandungan logam berat dalam larutan simulasi. Hal ini diduga polielektrolit yang terkandung dalam biokoagulan tersebut tidak memiliki gugus-gugus yang bermuatan negatif yang mampu mengikat ion-ion logam yang bermuatan positif. (Hendrawati, 2013:186). Biji kelor mengandung suatu zat aktif $4 \alpha$ - 4r- rhamnosyloxybenzylisothiocyanate yang berfungsi sebagai protein kationik. Zat aktif ini dapat membantu menurunkan gaya tolak menolak antara partikel koloid dalam air. Prinsip utama mekanismenya adalah adsorbs dan netralisasi tegangan protein tersebut. Ionion logam yang terlarut akan diadsorbsi oleh biji kelor sedangkan koloid yang terbentuk akan terjadi netralisasi muatan oleh protein yang terkandung dalam kelor tersebut (Adfa dkk, 2006 dalam Nugeraha, 2010:59).

\section{Kadar Besi (Fe)}

Kadar besi air olahan dengan menggunakan serbuk kernel kelor dan serbuk ampas kernel kelor berkisar antara 0.019-0.064 mg/L. Kadar besi rata-rata yang dihasilkan adalah $0.039 \mathrm{mg} . \mathrm{L}^{-1}$. Hasil analisis sidik ragam menunjukkan bahwa faktor perlakuan bahan koagulan alami dan perlakuan konsentrasi bahan koagulan alami berpengaruh sangat nyata $(\mathrm{P} \leq 0,01)$ terhadap kadar besi air olahan yang dihasilkan, sedangkan interaksi antar perlakuan berpengaruh tidak nyata $(\mathrm{P}>0.05)$ terhadap kadar besi air olahan yang dihasilkan. 


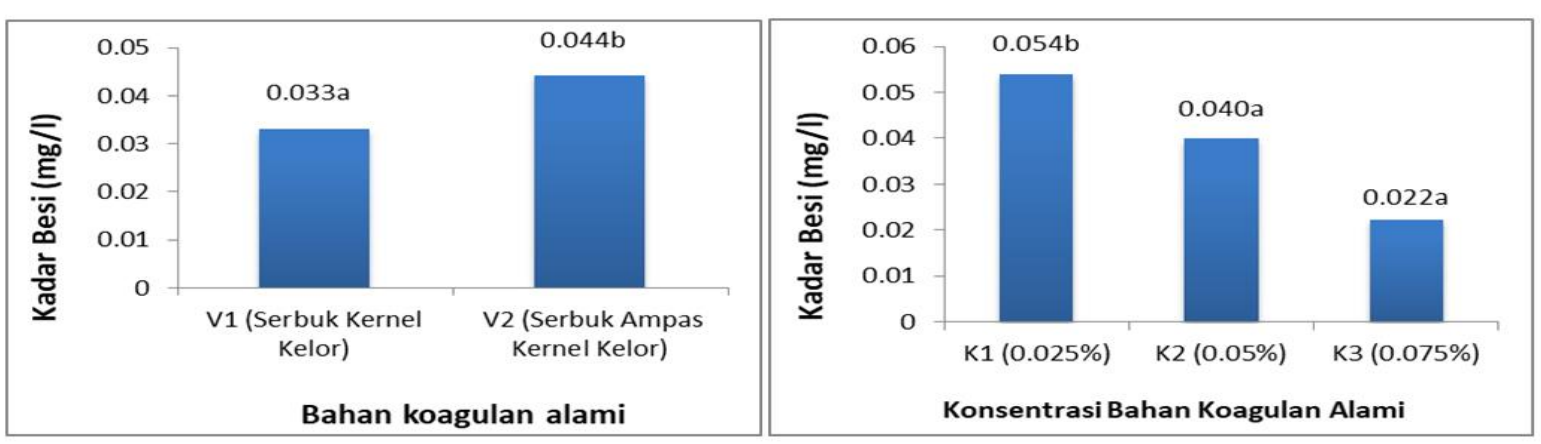

Gambar 5. Pengaruh biokoagulan terhadap kadar besi air olahan dan konsentrasi biokoagulan terhadap kadar besi air olahan yang dihasilkan

Gambar 5 menunjukkan bahwa kadar besi air olahan yang dihasilkan dari serbuk kernel kelor lebih rendah dibandingkan dengan serbuk ampas kernel kelor. Hal ini mengindikasikan bahwa terjadinya penurunan kadar besi di dalam air olahan sangat dipengaruhi oleh proses koagulasi.

Kadar besi air olahan yang dihasilkan pada konsentrasi serbuk kernel kelor dan serbuk ampas kernel kelor $0.025 \%$ lebih tinggi dibandingkan dengan konsentrasi $0.05 \%$. Hal ini mengindikasikan bahwa semakin tinggi konsentrasi serbuk kernel kelor dan serbuk ampas kernel kelor semakin banyak kandungan zat aktif rhamnosyloxy-benzil-isothiocyanate yang berperan dalam proses koagulasi, sehingga kandungan kadar besi di dalam air semakin cepat menyatu dengan gumpalan dan kadar besi air olahan yang dihasilkan menurun.

\section{Bakteri Koli Total}

Berdasarkan hasil penelitian, bakteri koli total air olahan dengan menggunakan serbuk kernel kelor dan serbuk ampas kernel kelor berkisar antara $0.02 \times 10^{2}-0.26 \times 10^{2} / 100 \mathrm{ml}$ sampel. Total bakteri koli rata-rata yang dihasilkan adalah $0.14 \times 10^{2} / 100 \mathrm{ml}$ sampel. Hasil analisis sidik ragam menunjukkan bahwa faktor perlakuan variasi biokoagulan dan perlakuan konsentrasi biokoagulan berpengaruh sangat nyata $(\mathrm{P} \leq 0.01)$ terhadap total bakteri koli air olahan yang dihasilkan, sedangkan interaksi antar perlakuan berpengaruh tidak nyata $(\mathrm{P}>0.05)$ terhadap bakteri koli total air olahan yang dihasilkan.

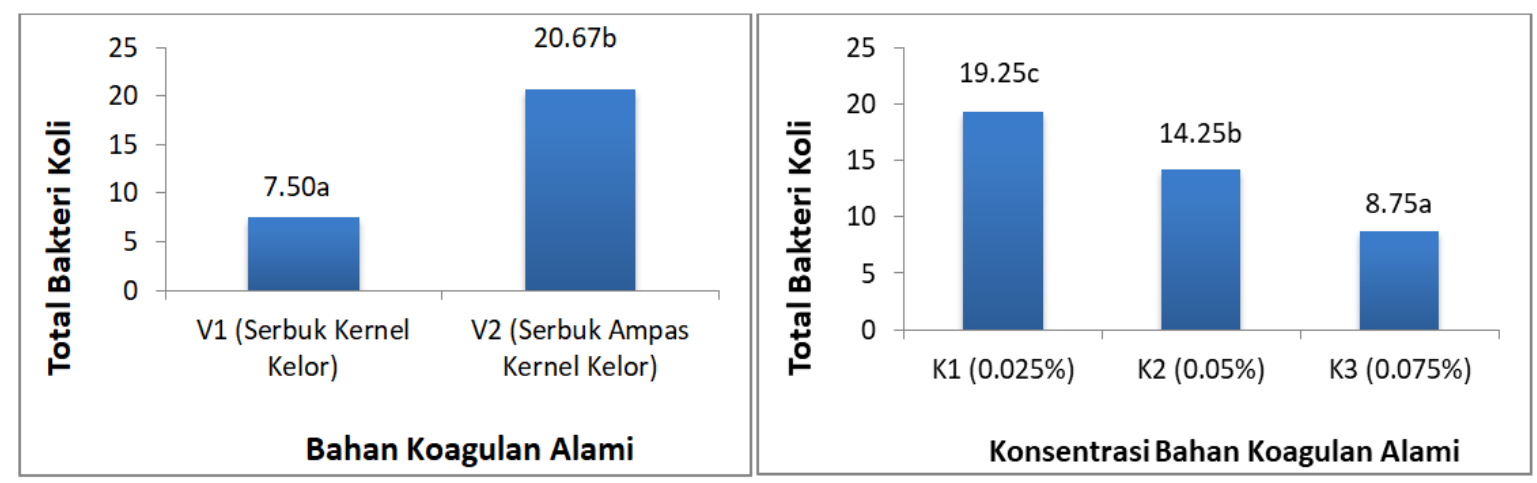

Gambar 6. Pengaruh biokoagulan terhadap bakteri koli total air olahan dan pengaruh konsentrasi biokoagulan terhadap bakteri koli total air olahan yang dihasilkan

Gambar 6 menunjukkan bahwa bakteri koli total air olahan yang dihasilkan dari serbuk kernel kelor lebih rendah dan berbeda sangat nyata dengan serbuk ampas kernel kelor. 
Kandungan zat aktif rhamnosyloxy-benzil-isothiocyanate yang tinggi dapat menyempurnakan proses koagulasi dan bakteri koli yang terkandung di dalam air ikut menempel pada flok yang terbentuk (Morton,1991).

Bakteri koli total air olahan yang dihasilkan pada konsentrasi serbuk kernel kelor dan serbuk ampas kernel kelor $0.025 \%$ lebih tinggi dan berbeda sangat nyata dengan konsentrasi $0.05 \%$ dan $0.075 \%$. Hal ini diduga karena serbuk kernel kelor dan serbuk ampas kernel kelor pada konsentrasi $0,05 \%$ dan $0,075 \%$ lebih banyak mengandung zat aktif rhamnosyloxy-benzilisothiocyanate yang juga berfungsi sebagai bahan desinfektan sehingga proses desinfeksi terjadi dengan baik dan jaringan sel bakteri dengan cepat dapat dimatikan. Menurut Nuwenda, dkk (2014), penurunan total bakteri selain karena adanya pengadukan kecepatan tinggi dan rendah juga adanya kandungan senyawa senyawa benzil-isothiocyanate pada serbuk kelor yang dapat mengganggu permeabilitas sel dan membran sel bakteri

\section{KESIMPULAN}

Faktor perlakuan variasi biokoagulan berpengaruh sangat nyata $(\mathrm{P} \leq 0,01)$ terhadap $\mathrm{pH}$, kekeruhan, kadar mangan (Mn), kadar besi (Fe), dan bakteri koli total dan berpengaruh nyata $(\mathrm{P} \leq 0,05)$ terhadap warna air olahan yang dihasilkan. Faktor perlakuan konsentrasi biokoagulan berpengaruh sangat nyata $(\mathrm{P} \leq 0,01)$ terhadap $\mathrm{pH}$, warna, kadar mangan $(\mathrm{Mn})$, kadar besi $(\mathrm{Fe})$, dan bakteri koli total dan berpengaruh tidak nyata $(\mathrm{P}>0,05)$ terhadap kekeruhan air olahan yang dihasilkan. Faktor interaksi perlakuan terhadap variasi biokoagulan dan konsentrasi biokoagulan berpengaruh tidak nyata $(\mathrm{P}>0,05)$ terhadap semua parameter analisis. Air olahan dengan kualitas terbaik adalah dengan perlakuan terhadap serbuk kernel kelor $\left(\mathrm{V}_{1}\right)$ dengan konsentrasi 0,05\% $\left(\mathrm{K}_{2}\right)$ dengan karakteristik sebagai berikut : $\mathrm{pH}$ 7,21, warna 11,25 TCU (True Colour Units), kekeruhan 2,38 NTU (Nephelometric Turbidity Units), kadar mangan (Mn) $0,022 \mathrm{mg} . \mathrm{L}^{-1}$, kadar besi $0,036 \mathrm{mg} \cdot \mathrm{L}^{-1}$, dan bakteri koli total $0,08 \times 10^{2} / 100 \mathrm{ml}$ sampel.

\section{DAFTAR PUSTAKA}

Amir, R. 2010. Penentuan Dosis Optimum Aluminium Sulfat Dalam Pengolahan Air Sungai Cileueur Kota Ciamis dan Pemanfaatan Resisrkulasi Lumpur Dengan Parameter pH, Warna, Kekeruhan, dan TSS. Jurnal. Teknik Lingkungan ITB, Bandung.

Haslinah, A. 2016. Optimalisasi serbuk biji kelor (Moringa oleifera) sebagai koagulan untuk menurunkan turbiditas dalam limbah cair industri tahu. ILTEK. 11 (22): 1629-1633.

Hendrawati. 2013 Penggunaan Biji Asam Jawa (Tamarindus indica L.) dan Biji Kecipir (Psophocarpus tetragonolobus L.) sebagai Koagulan Alami dalam Perbaikan Kualitas Air Tanah. Prosiding Semirata FMIPA Universitas Lampung, Lampung.

Karamah, E.F. dan Septiyanto, A. 2010. Pengaruh Suhu dan Tingkat Keasaman (pH) pada Tahap Perlakuan Koagulasi (Koagulan Aluminium Sulfat) dalam Proses Pengolahan Air Menggunakan Membran Mikrofiltrasi Polipropilen Hollow Fibre. Departemen Teknik Gas dan Petrokimia, Fakultas Teknik, Universitas Indonesia.

Luff, R. 2001. Oxfam water treatment. University of Surrey, London.

Morton, J.K. 1991. The orseadish tree Moringa pterygosperma (Moringaceae). Economic Botary, London.

Muyibi S.A. dan Evison L.M. 1995. Optimizing Physical Parameters Affecting Coagulation Of Turbid Water With Moringa Oleifera Seeds. Wat. Res. Vol. 29, No. 12, Pp. 2689 2695.

Nugeraha, 2010 Pengolahan Air Limbah Kegiatan Penambangan Batubara Menggunakan Biokoagulan : Studi Penurunan Kadar Tss, Total Fe Dan Total Mn Menggunakan Biji 
Kelor (Moringa Oleifera. Jurnal Presipitasi Vol. 7 No.2 September 2010, Issn

$1907-$ 187x. Semarang.

Nugroho, 2003, Evaluasi Kualitas Air Sungai Ciliwung DKI Jakarta Melalui Pendekatan Indeks

Kualitas Air National Sanitation Foundation, Tesis, Departemen Konservasi Sumber Daya Hutan, Fakultas Kehutanan, IPB, Bogor.

Nuwenda, Wewen dan Gandasasmita, S. 2011. Studi Efektivitas Campuran Serbuk Biji Kelor dan Tawas Sebagai Koagulan Terhadap Kation Logam Berat dalam Air Tanah. ISBN: 978-602-19655-0-4. Bandung.

Sutrisno, T. 1996. Teknologi penyediaan air bersih, Rineke Cipta, Jakarta.

Siahaan, R., A. Indawan, D. Soedharma, dan L.B. Prasetyo. 2011. Kualitas air sungai cisadane, Jawa Barat - Banten. Jurnal Ilmiah Sains. 11: 268-273.

Yuliastri I.R. (2010). Penggunaan Biji Kelor (Moringa oleifera) sebagai Koagulan dan Flokulan dalam Perbaikan Kualitas Air Limbah dan Air Tanah. Jakarta: Fakultas Sains dan Teknologi. Universitas Islam Negeri Syarif Hidayatullah Jakarta.

Widyaningsih, H.A. 2011. Resirkulasi Flok untuk Kekeruhan Rendah pada Kali Pelayaran Sidoarjo dengan Sistem Batch. Jurnal. Teknik Lingkungan ITS, Surabaya. 